\title{
TNFRSF4 wt Allele
}

National Cancer Institute

\section{Source}

National Cancer Institute. TNFRSF4 wt Allele. NCI Thesaurus. Code C95046.

Human TNFRSF4 wild-type allele is located in the vicinity of 1 p36 and is approximately 3 $\mathrm{kb}$ in length. This allele, which encodes tumor necrosis factor receptor superfamily member 4 protein, is involved in the modulation of apoptosis, inflammation, and signaling pathways. 